\title{
The impact of recycling of organic carbon on the stable carbon isotopic composition of dissolved inorganic carbon in a stratified marine system (Kyllaren fjord, Norway)
}

\author{
Y. van Breugel ${ }^{\mathrm{a}, *}$, S. Schouten ${ }^{\mathrm{a}}$, M. Paetzel ${ }^{\mathrm{b}}$, \\ R. Nordeide ${ }^{c}$, J.S. Sinninghe Damsté ${ }^{a}$ \\ a Royal Netherlands Institute for Sea Research, Department of Marine Biogeochemistry \& Toxicology, \\ PO Box 59, 1790 AB Den Burg, The Netherlands \\ ${ }^{\mathrm{b}}$ The Faculty of Science, HSF University College, PO Box 133, N-6851 Sogndal, Norway \\ ${ }^{\mathrm{c}} \mathrm{N}$-6980 Askvoll, Norway
}

Received 22 October 2004; accepted 12 March 2005

(returned to author for revision 15 January 2005)

Available online 24 May 2005

\begin{abstract}
A negative carbon isotope shift in sedimentary organic carbon deposited in stratified marine and lacustrine systems has often been inferred to be a consequence of the process of recycling of respired and, therefore, ${ }^{13} \mathrm{C}$-depleted, dissolved inorganic carbon (DIC) formed from mineralization of descending organic matter. To study this process, we measured $\delta^{13} \mathrm{C}_{\text {DIC }}$ and $\delta^{13} \mathrm{C}$ values of particulate organic carbon (POC) over an annual cycle in the permanently stratified Kyllaren fjord in Norway. A notable accumulation of respired DIC below the chemocline was evident from the substantially ${ }^{13} \mathrm{C}$ depleted DIC (ca. $-19 \%$ ). Especially in autumn to early spring, respired DIC from the deep anoxic water is mixed into the oxygenated surface water and the calculated respired DIC contribution to the total DIC pool was up to $40 \%$ in early spring in the upper $2 \mathrm{~m}$ of the water column. At $4 \mathrm{~m}$ depth, just below the chemocline, the respired DIC contribution reaches ca. $90 \%$ of the total DIC pool. Assimilation of the respired DIC seems to exert only a small effect on $\delta^{13} \mathrm{C}_{\mathrm{POC}}$, which has an average $\delta^{13} \mathrm{C}$ value of $-24 \%$. The measured photoautotrophic fractionation $\left(\varepsilon_{\mathrm{p}}\right)$ was low $(<10 \%)$ during the majority of the year. This is likely responsible for reducing the apparent impact of recycling of respired DIC on $\delta^{13} \mathrm{C}_{\mathrm{POC}}$. However, in June 2002, photoautotrophic use of the ${ }^{13} \mathrm{C}$-depleted DIC is obvious from a ${ }^{13} \mathrm{C}$-depletion of POC $(-33.7 \%)$ derived from a bloom of the protist Euglena sp.
\end{abstract}

(c) 2005 Elsevier Ltd. All rights reserved.

\section{Introduction}

The present day oceans are well mixed by thermohaline driven ocean currents, the so-called ocean conveyor

\footnotetext{
${ }^{*}$ Corresponding author. Tel.: +31 222 369580; fax: +31 222 319674.

E-mail address: breugel@nioz.nl (Y.van Breugel).
}

belt. However, during past "oceanic anoxic events" (OAEs; Schlanger and Jenkyns, 1976) larger parts of the ancient oceans were stratified, likely due to plate tectonics (Pletsch et al., 2000; Poulsen et al., 2001). Sediments deposited during such OAEs are often characterized by distinct lamination, good preservation of organic matter $(\mathrm{OM})$, low abundance or absence of benthic formaminifera and ${ }^{13} \mathrm{C}$-enriched organic carbon 
and carbonate (Arthur et al., 1990). The latter arises as a result of enhanced organic matter burial rates in anoxic water columns and sediments and, thus, removal of ${ }^{13} \mathrm{C}$ depleted organic matter from the ocean and atmosphere. However, during the Toarcian OAE and Aptian OAE 1a, carbonate and organic carbon also exhibit a negative carbon isotope excursion, occurring in strata immediately preceding the positive excursion often at the base of the black shales (Menegatti et al., 1998). This negative isotope excursion has been attributed to the massive release of ${ }^{13} \mathrm{C}$-depleted methane from gas hydrates (Hesselbo et al., 2000), analogous to the model proposed for a similar isotopic shift at the Late Paleocene Thermal Maximum (Dickens et al., 1995).

Küspert (1982) explained such a negative isotope excursion in a different way. According to his model, ${ }^{13} \mathrm{C}$-depleted $\mathrm{OM}$ is oxidized while sinking to bottom waters and ${ }^{13} \mathrm{C}$-depleted dissolved inorganic carbon (DIC) accumulates in the bottom waters. When this deep water DIC escapes to the photic zone by convection or diffusion, it is utilized by the plankton for calcification processes or photosynthesis (Fig. 1a). Long-lasting stratification and recycling of the respired
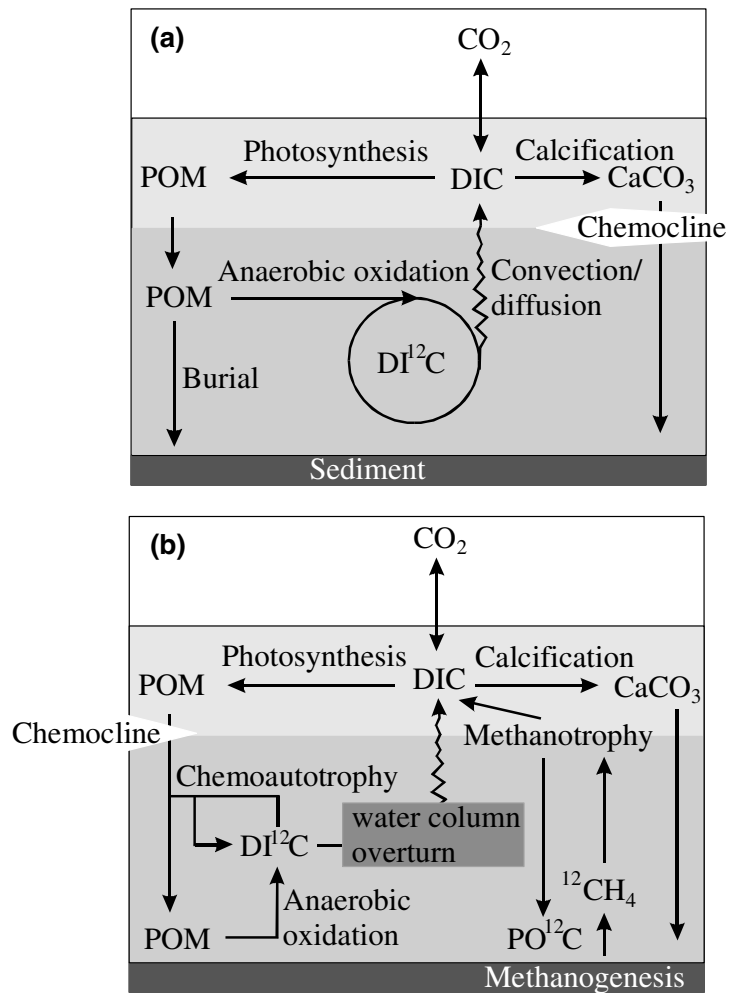

Fig. 1. (a) Model proposed by Küspert (1982) to explain negative $\delta^{13} \mathrm{C}$ excursion in sediments deposited during the Toarcian OAE and (b) model proposed by Hollander and Smith (2001) to explain negative trends in the $\delta^{13} \mathrm{C}$ of sedimentary organic carbon in stratified lakes.
$\mathrm{CO}_{2}$ may thus result in a decrease in $\delta^{13} \mathrm{C}$ value of organic carbon and carbonate in the sediment (Küspert, 1982; Schouten et al., 2000).

Evidence that this process of recycling of respired $\mathrm{CO}_{2}$ can affect the ${ }^{13} \mathrm{C}$ content of DIC has come from stable isotope studies of meromictic and monomictic lakes (Deevey et al., 1963; Deevey and Stuiver, 1964; Rau, 1978; Quay et al., 1986; Bernasconi and Hanselmann, 1995; Wachniew and Rózanski, 1997); ${ }^{13} \mathrm{C}$-depleted values for DIC ranging from $-4 \%$ up to values as low as $-22 \%$ were reported. The lowest $\delta^{13} \mathrm{C}_{\text {DIC }}$ values were observed for the anoxic bottom water (hypolimnion) where organic matter is oxidized. Moreover, the DIC in the epilimnion of such systems is ${ }^{13} \mathrm{C}$-depleted $\left(\delta^{13} \mathrm{C}_{\text {DIC }}\right.$ is $-4 \%$ to $-10 \%$ ) compared to global surface ocean $\delta^{13} \mathrm{C}_{\mathrm{DIC}}$ in equilibrium with the atmosphere $(+2 \%$ to $-0.5 \%$; Kroopnick, 1985). Consistent with the ${ }^{13} \mathrm{C}$-depleted DIC, $\delta^{13} \mathrm{C}$ values of particulate organic carbon (POC) in these systems is also substantially depleted, ranging from $-41.5 \%$ to $-47 \%$ o (Rau, 1978; Fry, 1986; Bernasconi and Hanselmann, 1995). Hollander and Smith (2001) noted a trend towards lower $\delta^{13} \mathrm{C}$ values of sedimentary organic and inorganic carbon due to intensified eutrophication in two stratified lakes. Their model explaining the negative trends in the $\delta^{13} \mathrm{C}$ of sedimentary organic carbon is comparable to that of Küspert (1982), with an expansion of seasonally driven water column overturn in combination with an important bacterial contribution to the total sedimentary carbon pool (Fig. 1b).

In contrast to lake systems, stratified marine systems have been less well studied with respect to recycling of respired DIC. Permanently stratified marine systems are confined to relatively small (semi) enclosed basins, generally with a narrow connection and/or a shallow sill to the open ocean, thereby restricting water circulation. In the Black Sea, the largest anoxic basin (Murray et al., 1991), a sharp decrease in $\delta^{13} C_{\text {DIC }}$ between 40 and $60 \mathrm{~m}$ depth and a more gradual decrease to ca. $-6 \%$ below $1000 \mathrm{~m}$ depth is ascribed to remineralization of organic matter (Fry et al., 1991; Volkov, 2000). However, $\delta^{13} \mathrm{C}$ values of POC and biolipids in the water column and $\delta^{13} \mathrm{C}$ values of TOC and lipids in the sediment do not reveal use of the respired DIC by photoautotrophs (Freeman et al., 1994). Other examples of oxygen-deficient marine waters are found in many threshold fjords (Richards, 1965; Syvitski et al., 1987; Paetzel and Schrader, 1995). For example, Velinsky and Fogel (1999) measured isotopic compositions of DIC and POC in Framvaren fjord, Norway, which ranged from $-2 \%$ to $-20 \%$ o and $-23 \%$ to $-32 \%$, respectively, suggesting a strong impact of recycling of $\mathrm{CO}_{2}$.

In order to determine the significance of recycling of respired DIC in the photic zone and its impact on $\delta^{13} \mathrm{C}$ values of POC in stratified marine systems, we performed a seasonal study of stable carbon isotope ratios 
of DIC and POC in different water layers of a stratified fjord (Kyllaren) in Norway. This small, permanently anoxic fjord seems to be suitable as a model for the study of the effects of respired $\mathrm{CO}_{2}$ on the isotopic composition of $\mathrm{OM}$, since the presence of ${ }^{13} \mathrm{C}$-depleted lipids of green and purple sulfur bacteria in the surface sediment indicate the prominence of this process (Smittenberg et al., 2004). The results are interpreted in the context of the carbon cycle models presented above and the potential consequences for the carbon isotopic composition of sedimentary organic carbon.

\section{Experimental}

\subsection{Site description}

Kyllaren is a small, $29 \mathrm{~m}$ deep fjord on the west coast of Norway $\left(62^{\circ} \mathrm{N}, 5^{\circ} \mathrm{E}\right)$, connected to the Norwegian Sea by a narrow, 1-2 $\mathrm{m}$ deep channel (Fig. 2). Precipitation and river run-off establish a low salinity surface layer and permanent salinity stratification has developed in

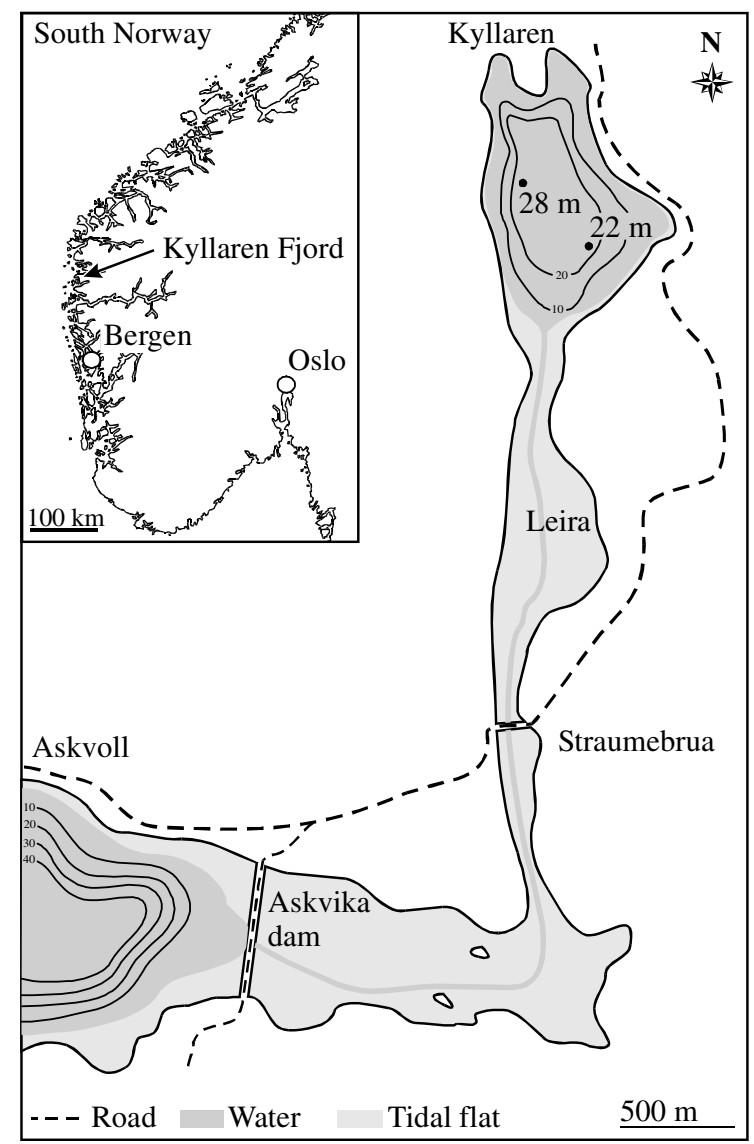

Fig. 2. Geographical setting of Kyllaren fjord, Norway. It lies approximately at $61^{\circ} 25^{\prime} \mathrm{N}$ and $5^{\circ} 10^{\prime} \mathrm{E}$ (Smittenberg et al., 2004). the fjord at least since 1993. In 1954, a $50 \mathrm{~m}$ dam with a ca. $5 \mathrm{~m}$ opening was built in the Leira and fish disappeared from the North side of the dam. In 1988, a $450 \mathrm{~m}$ long dam was built in Askvika, with two openings of $15 \mathrm{~m}$. Since the narrowing of the channel, anoxia gradually built up in the bottom waters until a release of hydrogen sulfide to the atmosphere was first observed in 1993, indicating that the chemocline had risen to the surface water. The conditions for the Küspert model are met by the permanent position of the chemocline just below, or even in, the photic zone.

\subsection{Sampling}

Water samples for DIC concentration ([DIC]), stable carbon isotope ratios of DIC $\left(\delta^{13} \mathrm{C}_{\mathrm{DIC}}\right)$, POC concentration ([POC]) and stable carbon isotope ratio of POC $\left(\delta^{13} \mathrm{C}_{\mathrm{POC}}\right)$ were taken at a fixed sample position in the fjord at the depocentre ( $28 \mathrm{~m}$ water depth), except for the sampling in February 2003. At that time, ice covered about $70 \%$ of the fjord and the regular sampling position could not be reached. Instead, samples were taken at a position closer to the southeast coast at a water depth of $22.5 \mathrm{~m}$ (Fig. 2). Duplicate water samples were taken with a 21 Niskin bottle through the water column at $0 \mathrm{~m}$ (surface), 2, 4, 6, 8, 10, 15, 20 and $25 \mathrm{~m}$ depth for [DIC] and $\delta^{13} \mathrm{C}_{\text {DIC }}$ measurements. Only single [DIC] measurements were carried out for surface and $2 \mathrm{~m}$ water depth in April 2002. No samples were taken at 2 and $8 \mathrm{~m}$ depth for [POC] and $\delta^{13} \mathrm{C}_{\mathrm{POC}}$ in September 2002. In February 2003 DIC and POC samples were taken at different depths: $0.5,2,4,6,8,10,15$ and $20 \mathrm{~m}$ depth.

Temperatures were measured with a thermometer inside the Niskin bottle or in situ with YSI 85 equipment. Salinity was measured using STD/CTD model SD204, manufacturer SAIV A/S Environmental Sensors \& Systems (optional sensor unit 106) or YSI 85 equipment, whilst oxygen was measured with STD/CTD model SD204. The $\mathrm{pH}$ was measured in situ or in the laboratory directly after the fieldwork with a GK2401C Radiometer Electrode. Samples for hydrogen sulfide concentration $\left(\left[\mathrm{HS}^{-}\right]\right.$) were taken in June 2002 (single samples), August 2002 and April 2003 (duplicate samples). A sediment core was taken in September 2002 using a gravity corer and the upper $17 \mathrm{~cm}$ was sampled every $0.5 \mathrm{~cm}$ for TOC and bulk organic $\delta^{13} \mathrm{C}$ analyses.

Water samples for [DIC] were filtered over $0.2 \mu \mathrm{m}$ acrodisc filters into $3 \mathrm{ml}$ vials and the vials were sealed free from air and transported to the laboratory. Samples for $\delta^{13} \mathrm{C}_{\text {DIC }}$ were taken according to the DOE Handbook of Methods (Eds. Dickson and Goyet, 1994). Briefly, $100 \mathrm{ml}$ glass bottles were filled to the neck with sample water; $20 \mu \mathrm{l}$ of a saturated $\mathrm{HgCl}$ solution was added and the bottle was filled and closed free from air with a butyl rubber cap. In the samples containing 
$\mathrm{HS}^{-}, 20 \mu \mathrm{l}$ of saturated $\mathrm{FeCl}_{2}$ was added to precipitate the sulfide, before the $\mathrm{HgCl}$ solution was added. Samples for $\left[\mathrm{HS}^{-}\right]$were taken as for the [DIC] samples, with $20 \mu \mathrm{l}$ of a $1 \mathrm{~N} \mathrm{NaOH}$ solution added to the empty vial in advance. The water samples were stored cool and in the dark until analysis.

For [POC] and $\delta^{13} \mathrm{C}_{\mathrm{POC}}$ determinations, water was pumped into a 201 pressure tank with a $12 \mathrm{~V}$ car battery-operated pump. Two separate batches each of 101 of water were filtered over pre-combusted $\left(400{ }^{\circ} \mathrm{C}\right)$ $0.7 \mu \mathrm{m}$ glass fibre filters in a $150 \mathrm{~mm}$ in-line filter holder. The filters were packed in aluminum foil and kept frozen in the dark. Before analysis they were freeze-dried.

\subsection{Analyses}

DIC concentration, sulfide concentration and $\delta^{13} \mathrm{C}_{\text {DIC }}$ were usually measured within two weeks of sampling. [DIC] and $\left[\mathrm{HS}^{-}\right]$analyses were carried out as described by Stoll et al. (2001) with a Technicon Traacs 800 autoanalyzer; $\delta^{13} \mathrm{C}_{\text {DIC }}$ values were determined by headspace analysis of $0.5-2 \mathrm{ml}$ (depending on [DIC]) of water which had reacted with $100 \% \mathrm{H}_{3} \mathrm{PO}_{4}$ for at least $1 \mathrm{~h}$ at room temperature. The headspace was analyzed using a Thermofinnigan Gas Bench II coupled to a Delta ${ }^{\text {PLUS }}$ irm/MS system. Stable carbon isotope ratios were determined relative to lab. standards calibrated against NBS 18 carbonate (IAEA) and reported relative to Vienna Pee Dee Belemnite (VPDB) in standard delta notation. For [POC] and $\delta^{13} \mathrm{C}_{\mathrm{POC}}$ analyses, circles of $6-56 \mathrm{~mm}^{2}$ (depending on the [POC]) were punched out of the filters and folded into tin cups. The filters were used without further treatment, as tests had shown that inorganic carbon did not contribute to the carbon pool on the filter. Sediment samples were freeze-dried and decarbonated with $1 \mathrm{~N} \mathrm{HCl}$ solution and washed with demineralized water. [POC], $\delta^{13} \mathrm{C}_{\mathrm{POC}}$ and sedimentary TOC and $\delta^{13} \mathrm{C}_{\mathrm{TOC}}$ were determined using elemental analysis (EA)/isotope-ratio-monitoring mass spectrometry (EA/irmMS). EA/irmMS analysis was performed with filtered OM using a Carlo Erba Flash elemental analyzer coupled to a Thermofinnigan Delta ${ }^{\text {PLUS }}$ irmMS system. The total organic carbon content (as weight percentage) was determined using external standards with known carbon content and corrected using a blank filter folded in a tin cup. Stable carbon isotope ratios were determined using lab. standards calibrated with NBS 22 oil (IAEA) and reported relative to VPDB in standard delta notation.

Standard deviations for $\delta^{13} \mathrm{C}_{\text {DIC }}$ were generally between $0.1 \%$ and $0.6 \%$ (average $0.3 \%$ ). The standard deviations of the [DIC] and [ $\left.\mathrm{HS}^{-}\right]$duplicates, expressed as a percentage of the average value, were generally $<8 \%$. The sometimes rather large standard deviation in [POC] (1-46\%, average $11 \%)$ and $\delta^{13} \mathrm{C}_{\mathrm{POC}}(0.1-2.1$, average $0.6 \%$ ) could be explained by the heterogeneity of the $\mathrm{OM}$ and its uneven distribution on the filter.

The $\left[\mathrm{CO}_{2}(\mathrm{aq})\right]$ was calculated from [DIC], pH, salinity, depth and temperature with a $\mathrm{CO}_{2}$ speciation program (Stoll, 1994).

\section{Results}

In the surface layer to 4-5 m depth, a density $\left(\sigma_{\mathrm{t}}\right)$ less than 16 is maintained throughout the year in Kyllaren fjord, while a $\sigma_{\mathrm{t}}$ of 18-20 prevails in the deeper water (Fig. 3). The oxygen concentration decreases rapidly from $7-14$ to $0 \mathrm{mg} / \mathrm{l}$ between 2 and $6 \mathrm{~m}$ depth, while the sulfide concentration increases sharply to $\sim 5 \mathrm{mmol} / 1$. The position of the $\mathrm{O}_{2} / \mathrm{HS}^{-}$-interface (chemocline) is usually around $3.5 \mathrm{~m}$ depth but moved up to $0.5 \mathrm{~m}$ depth in the spring of 2001 and to $2 \mathrm{~m}$ depth in the winter of 2003. In winter/spring of 2002 the chemocline did not move from its regular position just above $4 \mathrm{~m}$ depth (Fig. 3). Periods of sulfide outgassing occurred in March 1994, February 1996, March 2000 and in February 2003. After a period of $\mathrm{H}_{2} \mathrm{~S}$ outgassing in April 2003 (Julian day 580), [HS ${ }^{-}$increased more gradually between 2 and $20 \mathrm{~m}$ depth and the maximum value was lower $(3.7 \mathrm{mmol} / \mathrm{l})$ than the ca. $5 \mathrm{mmol} / \mathrm{l} \mathrm{mea-}$ sured in the summer of 2002.

The [DIC] increased with a sharp gradient from $\sim 1 \mathrm{mmol} / 1$ in the surface waters to $\sim 11 \mathrm{mmol} / 1$ at $6 \mathrm{~m}$ depth (Fig. 4a). Interestingly, in February 2003 (Julian day 536), when the chemocline rose to a depth between 1.5 and $2 \mathrm{~m}$, [DIC] at $2 \mathrm{~m}$ depth was about four times higher than in other seasons, whilst the maximum [DIC] in deeper water at that time dropped to 9.6 mmol/l (Fig. 5a). In April 2003 (Julian day 583) maximum [DIC] below the chemocline was again $9.6 \mathrm{mmol} / \mathrm{l}$, but the [DIC] at $2 \mathrm{~m}$ depth had decreased to $1.8 \mathrm{mmol} / \mathrm{l}$ (Fig. 4a). The $\delta^{13} \mathrm{C}_{\text {DIC }}$ below $6 \mathrm{~m}$ depth was constant at $-19.0 \pm 0.5 \%$ throughout the year (Figs. $4 b$ and $5 b$ ). Above the chemocline $\delta^{13} \mathrm{C}$ varied on a seasonal basis from $+0.3 \%$ in June 2002 to $-6.5 \%$ in April 2003 (Figs. $4 \mathrm{c}$ and $5 \mathrm{~b}$ ). At $2 \mathrm{~m}$ depth the variation in $\delta^{13} \mathrm{C}_{\text {DIC }}$ was greatest, i.e., $15 \%$, with a $-15 \%$ minimum value in February 2003, when the water at $2 \mathrm{~m}$ depth was euxinic (Fig. 5b).

[POC] generally fluctuated between 35 and $260 \mathrm{mg}$ OC/1, with maxima concentrations at $2-4 \mathrm{~m}$ depth. The highest [POC] of $1600 \mathrm{mg} \mathrm{OC} / \mathrm{l}$ was reached in June 2002 during a bloom of the protist Euglena sp. at $4 \mathrm{~m}$ depth (Fig. 4c); microscopy indicated that the POC was derived largely from the Euglena species. Deep water $\delta^{13} \mathrm{C}_{\text {POC }}(6-25 \mathrm{~m}$ depth) varied little with depth $( \pm 2 \%)$ and in a seasonal cycle ranged from $-23.5 \%$ to $-33.4 \%$, with the lowest values in the summer of 2001 and 2002, i.e., Julian day 1 and 283. At $4 \mathrm{~m}$ depth $\delta^{13} \mathrm{C}_{\mathrm{POC}}$ varied in similar fashion to the $\delta^{13} \mathrm{C}_{\mathrm{POC}}$ of 


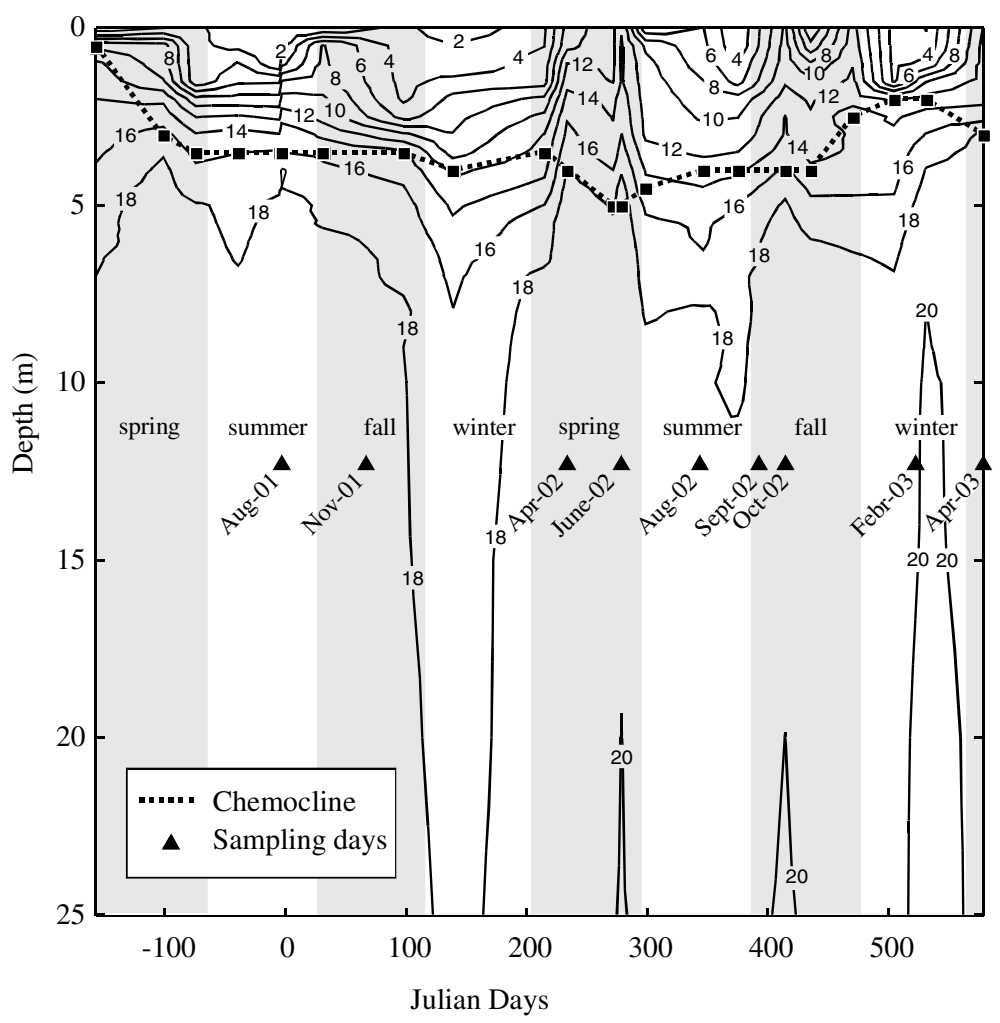

Fig. 3. Density contours $\left(\sigma_{\mathrm{t}}\right)$ and the $\mathrm{O}_{2} / \mathrm{HS}^{-}$interface in Kyllaren fjord through the seasons for March 2001-March 2003. Julian day 0 is set to August 20, 2001.

(a) $[\mathrm{DIC}](\mathrm{mmol} / \mathrm{l})$

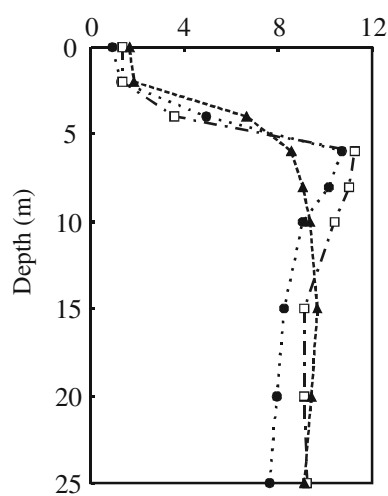

(b) $[\mathrm{POC}](\mathrm{mg} / \mathrm{l})$

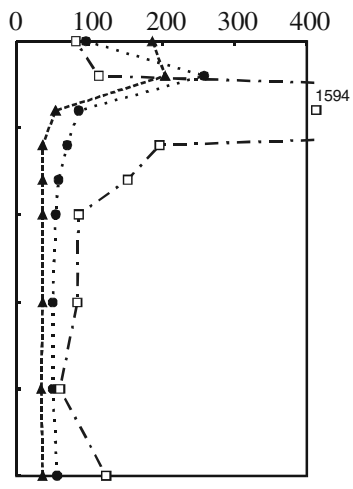

(c) $\delta^{13} \mathrm{C}_{\mathrm{DIC}}(\% 0)$

(d) $\delta^{13} \mathrm{C}_{\mathrm{POC}}(\% 0)$

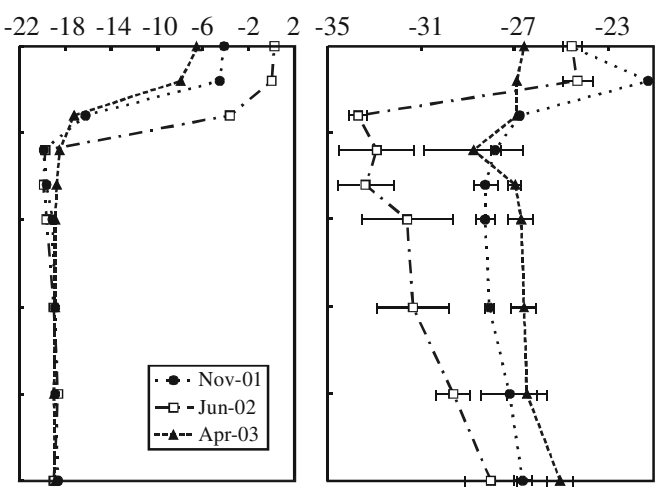

Fig. 4. Profiles of DIC concentration, POC concentration, $\delta^{13} \mathrm{C}$ of DIC and $\delta^{13} \mathrm{C}$ of POC through the water column in Kyllaren fjord. The depth profiles of November 2001, June 2002 and April 2003 represent the whole range of concentrations and stable carbon isotope ratios measured over the year.

the deeper waters, with a minimum of $-33.7 \%$ in June 2002 at the time of the Euglena bloom and a maximum of $-22.8 \%$ in October 2002 (Figs. 4d and 5c). The $\delta^{13} \mathrm{C}_{\mathrm{POC}}$ exhibited a different seasonal cycle in the surface water and values ranged from $-19 \%$ (Julian days 348 and 419 ) to $-27 \%$ (Julian days 527 and 583; Fig. $5 c)$.
In the sediment core, three facies could be distinguished: OM-rich fluff $(0-3 \mathrm{~cm})$, black mud (3$13.5 \mathrm{~cm})$ and olive-green mud $(13.5-40 \mathrm{~cm})$. The $\delta^{13} \mathrm{C}_{\text {TOC }}$ values varied between $-25.0 \%$ and $-25.5 \%$ in the olive-green mud $(13.5-17 \mathrm{~cm}),-25.4 \%$ to $-26.7 \%$ in the black mud and $-25.8 \%$ to $-26.2 \%$ in the upper $3 \mathrm{~cm}$ (Fig. 6). According to the age model of 


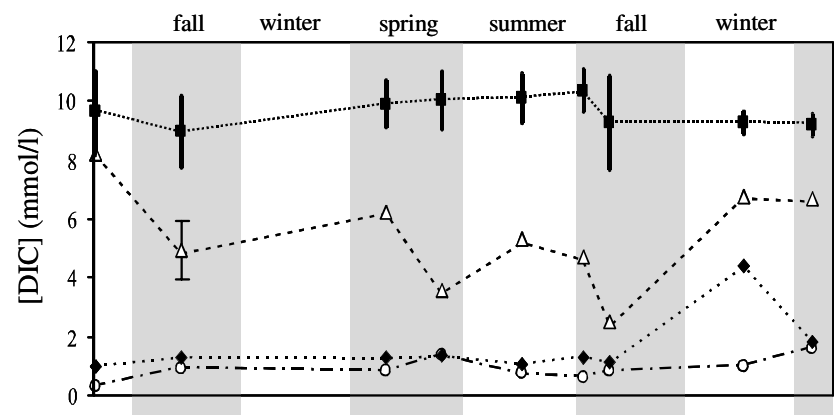

(a)

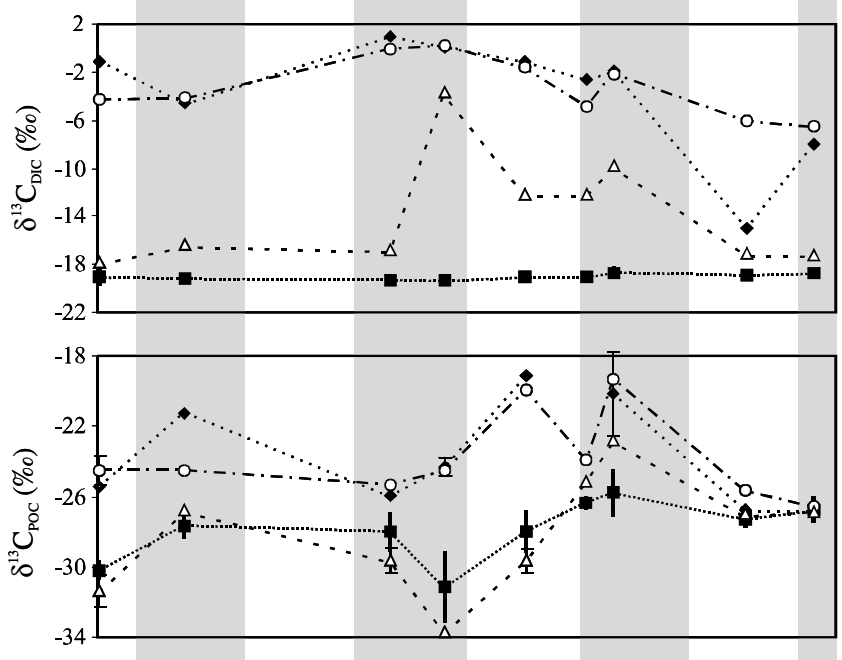

(b)

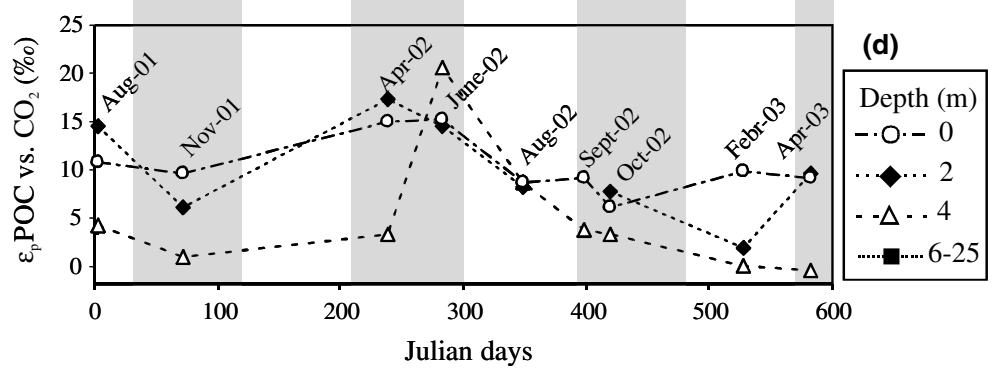

Fig. 5. Seasonal change (from August 2002 to April 2003) in: (a) DIC concentration; (b) $\delta^{13} \mathrm{C}$ of DIC; (c) $\delta^{13} \mathrm{C}$ of POC; (d) fractionation $\left(\varepsilon_{\mathrm{p}}\right)$ of $\mathrm{CO}_{2}$ to POC through the water column in Kyllaren fjord.

Smittenberg et al. (2004), sediments at 4 to $5.5 \mathrm{~cm}$ depth with the most negative $\delta^{13} \mathrm{C}_{\mathrm{TOC}}$ values $(-26.7 \%$ ) were deposited around the time that a $50 \mathrm{~m}$ dam was built in the Leira (Fig. 2). The intensification of anoxia in Kyllaren fjord, since the building of the dams in 1954 and 1988 , is recorded in the upper $5 \mathrm{~cm}$ of the sediment core (Smittenberg et al., 2004).

\section{Discussion}

\subsection{Respiration of organic matter as a source for DIC}

Due to density stratification throughout the year, two chemically distinct water layers are prevalent in the fjord. The low salinity (i.e., $<16 \%$ o $)$ surface water $(0-$ $3.5 \mathrm{~m}$ ) contains oxygen for the largest part of the year. Directly below the chemocline, the water has high sulfide and DIC concentrations of up to 5 and $11 \mathrm{mmol} / \mathrm{l}$, respectively, and a simultaneous drop in $\delta^{13} \mathrm{C}_{\text {DIC }}$ to constant values of ca. $-19 \%$. This pattern of increasing DIC concentration with depth, coupled with decreasing $\delta^{13} \mathrm{C}_{\text {DIC }}$ values, was also reported for the Black Sea (Fry et al., 1991), Framvaren fjord (Velinsky and Fogel, 1999) and several meromictic lakes (Deevey et al., 1963; Rau, 1978). This indicates that respiration of OM substantially contributes to the DIC pool in Kyllaren fjord.

The $\delta^{13} \mathrm{C}$ values of primary OM and the contribution of respired DIC to the total bottom water DIC can be 


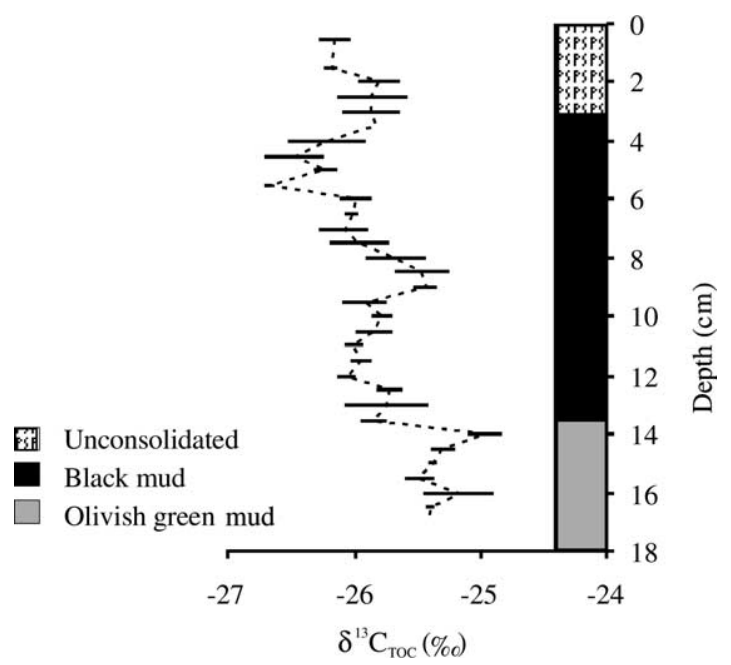

Fig. 6. $\delta^{13} \mathrm{C}$ of organic carbon in upper $18 \mathrm{~cm}$ sediment at depocentre of Kyllaren fjord. Lines indicate standard deviation.

calculated using mass balance equations as reported by Fry et al. (1991):

$$
\begin{aligned}
& \delta^{13} \mathrm{C}_{\mathrm{D}} \times[\mathrm{D}]= \delta^{13} \mathrm{C}_{\mathrm{atm}} \times\left[\mathrm{DIC}_{\mathrm{atm}}\right]+\delta^{13} \mathrm{C}_{\text {resp }} \\
& \times\left([\mathrm{D}]-\left[\mathrm{DIC}_{\mathrm{atm}}\right]\right), \\
& \delta^{13} \mathrm{C}_{\mathrm{D}}=\left(\delta^{13} \mathrm{C}_{\mathrm{atm}}-\delta^{13} \mathrm{C}_{\mathrm{resp}}\right) \cdot\left[\mathrm{DIC}_{\mathrm{atm}}\right] \times \frac{1}{[\mathrm{D}]}+\delta^{13} \mathrm{C}_{\text {resp }} .
\end{aligned}
$$

With $\mathrm{D}=$ measured DIC, $\mathrm{C}_{\mathrm{atm}}=$ DIC in equilibrium with atmospheric $\mathrm{CO}_{2}$ and $\mathrm{C}_{\text {resp }}=$ respired carbon. A linear plot of measured $\delta^{13} \mathrm{C}$ vs. [DIC] ${ }^{-1}$ provides the $\delta^{13} \mathrm{C}$ values of respired carbon added at depth as the $y$ intercept $\left(\sim-20 \%\right.$; Fig. 7). This $\delta^{13} \mathrm{C}$ value is comparable with the average $\delta^{13} \mathrm{C}_{\mathrm{POC}}$ in the surface water $(-22 \pm 3 \%$ ) of the fjord, confirming the idea that a large part of the DIC is derived from mineralized OM. The small ${ }^{13} \mathrm{C}$ enrichment in respired DIC compared to POC could be due to fractionation during the mineralization process. In an experiment with marine copepods grazing on algae, Klein Breteler et al. (2002) found a $0.8 \%$ enrichment in respired $\mathrm{CO}_{2}$ relative to the isotopic composition of the food. The contribution of respired DIC to the DIC pool in the bottom water $(6-25 \mathrm{~m}$ depth) is ca. $95 \%$, assuming that $\delta^{13} \mathrm{C}_{\mathrm{DIC}}$ derived from atmospheric $\mathrm{CO}_{2}$ has a value of $\sim 1 \%$ (Fry et al., 1991). This notable accumulation of respired $\mathrm{CO}_{2}$ in the bottom water fulfills one of the main prerequisites for the respired carbon recycling model proposed by Küspert (1982).

Another requirement for the Küspert model is that the respired $\mathrm{CO}_{2}$ will become available for photoautotrophic organisms at and above the chemocline. In early summer $2002, \delta^{13} \mathrm{C}_{\mathrm{DIC}}$ values are close to $0 \%$

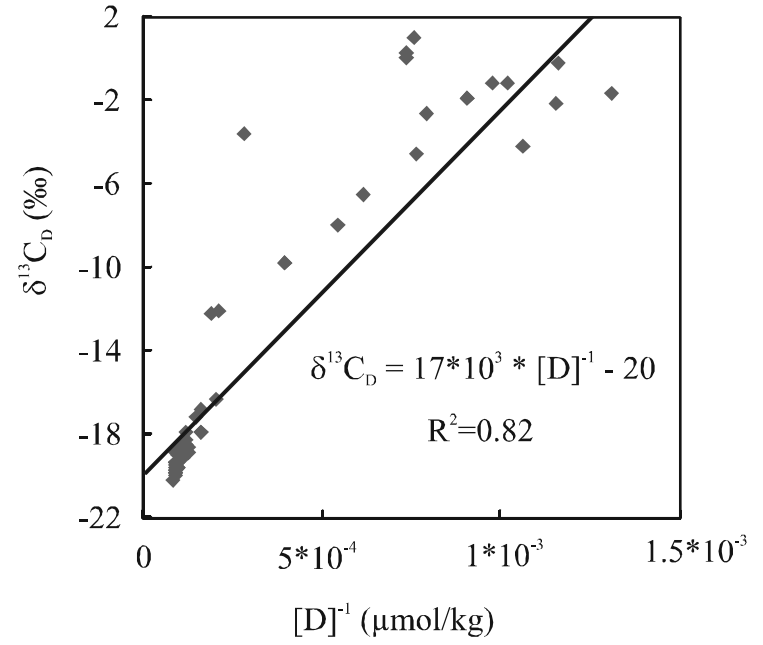

Fig. 7. The $\delta^{13} \mathrm{C}$ of respired DIC added at depth is provided by the $y$ intercept in linear plot of measured $\delta^{13} \mathrm{C}$ of DIC $\left(\delta^{13} \mathrm{C}_{\mathrm{D}}\right)$ vs. inverse of DIC concentration $\left([\mathrm{D}]^{-1}\right)$.

at 0 and $2 \mathrm{~m}$ depth in Kyllaren fjord, within the range of the global surface ocean variation $(+2 \%$ to $-0.5 \%$; Kroopnick, 1985). However, the more ${ }^{13} \mathrm{C}$-depleted DIC in the oxygenated surface water in autumn to early spring suggests a contribution from respired DIC coming from the bottom water. Using the mass balance equation [Eq. (I)], this contribution is calculated to be $\sim 5 \%$ in the summer, and up to $\sim 40 \%$ in April 2003 (Julian day 583). Storms are prevalent in the months October-March (DNMI, 2004) and are likely to be responsible for the $10-20 \%$ respired DIC contribution observed in the autumn of 2001 and 2002. The high respired DIC contribution in April 2003 is probably due to the ice cover that developed in February 2003 (Fig. 5b). Density stratification was weakened by cooling and salt exclusion and the chemocline rose to less than $2 \mathrm{~m}$ depth (Fig. 3). Curiously, no shallowing of the chemocline occurred in the winter of 2002 (Fig. 3), even though ice covered the fjord until March 2002 (interrupted by periods of thawing). Accordingly, no mixing was evident from $\delta^{13} \mathrm{C}_{\text {DIC }}$ values in April 2002 (Julian day 238).

The largest $\delta^{13} \mathrm{C}_{\text {DIC }}$ variation occurs close to the location of the chemocline, at $4 \mathrm{~m}$ depth. This water mixes freely with the anoxic bottom water during most of the year and the DIC available to anaerobic photosynthesis is $90 \%$ derived from respired DIC. Even in June 2002 (Julian day 283), when the chemocline moved below $4 \mathrm{~m}$ depth, the respired DIC contribution was still $\sim 20 \%$. The substantially ${ }^{13} \mathrm{C}$-depleted DIC in the surface waters available for photosynthesis during certain periods in the annual cycle, indicates the potential for recycling of respired DIC in Kyllaren fjord. 


\subsection{Impact of respired DIC on the stable carbon isotopic composition of $P O C$}

The stable carbon isotopic composition of POC at 0 and $2 \mathrm{~m}$ depth, where POC is likely to be derived predominantly from phytoplankton, varies between $-19 \%$ and $-27 \%$. These values do not immediately suggest the respired $\mathrm{CO}_{2}$ as a major contributor to inorganic carbon fixed by photoautotrophs, when compared with the ${ }^{13} \mathrm{C}$ content generally found for surface ocean $\mathrm{OM}$ derived from phytoplankton (ca. $-18 \%$ to $-24 \%$; Tyson, 1995). However, the $\delta^{13} \mathrm{C}_{\mathrm{POC}}$ is to a large extent also dependent on the isotopic fractionation during photosynthesis (Descolas-Gros and Fontagne, 1990). The photoautotrophic carbon isotope fractionation, $\varepsilon_{\mathrm{p}}$ (POC vs. $\mathrm{CO}_{2}$ ), in Kyllaren fjord was calculated using the following equation:

$\varepsilon_{\mathrm{p}}=\left(\left(\frac{1000+\delta^{13} \mathrm{C}_{\mathrm{CO}_{2}}}{1000+\delta^{13} \mathrm{C}_{\mathrm{POC}}}\right)-1\right) \times 1000$.

The calculated $\varepsilon_{\mathrm{p}}$ ranges from $6 \%$ to $17 \%$ at 0 and $2 \mathrm{~m}$ depth (Fig. 5d), a substantially larger range than that observed for $\delta^{13} \mathrm{C}_{\text {DIC }}$ in surface waters $(1 \%$ to $-8 \%$ o. Notably, $\varepsilon_{\mathrm{p}}$ is smaller than $10 \%$ during late summer to winter, when the respired DIC contribution increases; $\varepsilon_{\mathfrak{p}}$ is relatively small compared with the maximum fractionation associated with Rubisco for marine photosynthetic algae (ca. 25\%; Sharkey and Berry, 1985; Popp et al., 1998; Riebesell et al., 2000). This explains why $\delta^{13} \mathrm{C}_{\mathrm{POC}}$ is not as negative as we would suspect from the availability of respired DIC.

One of the factors that could lead to a small $\varepsilon_{\mathrm{p}}$ in Kyllaren fjord is a low $\mathrm{CO}_{2}$ concentration. An inverse relationship between $\varepsilon_{\mathrm{p}}$ (POC vs. $\mathrm{CO}_{2}$ ) and $\left[\mathrm{CO}_{2}(\mathrm{aq})\right]^{-1}$ should exist if $\left[\mathrm{CO}_{2}(\mathrm{aq})\right]$ is the dominant factor in controlling photosynthetic fractionation (Farquhar et al., 1982; Rau et al., 1992; Francois et al., 1993), especially in the case of low concentrations of $\mathrm{CO}_{2}$ (i.e., $<20 \mu \mathrm{M}$; Francois et al., 1993; Riebesell et al., 2000). The calculated $\left[\mathrm{CO}_{2}(\mathrm{aq})\right]$ in the fjord varies between 1 and $300 \mu \mathrm{M}$ in the surface waters (not taking into account February 2003 when the chemocline rose to $2 \mathrm{~m}$ depth). We calculated $\delta^{13} \mathrm{C}_{\mathrm{CO}_{2}}$ aq (Mook et al., 1974) for the upper two meters of Kyllaren fjord and observed a variation from $-9 \%$ to $-18 \%$. The lack of correlation in the plot of $\varepsilon_{\mathrm{p}}$ vs. $\left[\mathrm{CO}_{2}\right]^{-1}$ (Fig. 8), suggests that $\left[\mathrm{CO}_{2}\right]$ is not the main factor controlling $\varepsilon_{\mathrm{p}}$. More likely, variations in calculated $\varepsilon_{\mathrm{p}}$ values, and thereby $\delta^{13} \mathrm{C}_{\mathrm{POC}}$ variations, are mainly determined by the heterogeneity of particulate $\mathrm{OM}$, i.e., from multiple planktonic sources (e.g., diatoms, cyanobacteria, green algae), all with their own ${ }^{13} \mathrm{C}$ fractionation patterns (Popp et al., 1998) and contributing in varying amounts to POC. In cases were $\varepsilon_{\mathrm{p}}$ values are small $(<10 \%)$ compared to values normally associated with diffusive uptake of $\mathrm{CO}_{2}(20-25 \%)$, it is

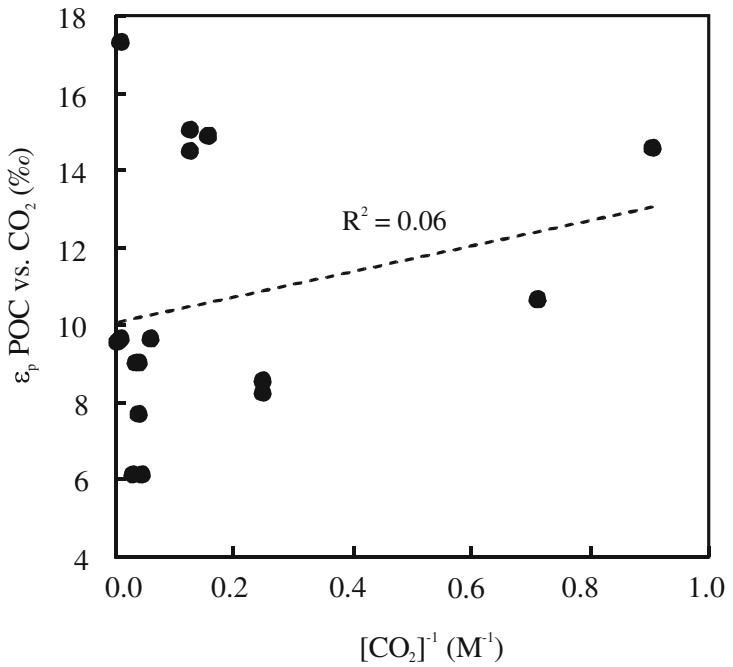

Fig. 8. An inverse relationship between the fractionation $\varepsilon_{\mathrm{p}}$ and $\left[\mathrm{CO}_{2} \mathrm{aq}\right]^{-1}$ (Farquhar et al., 1982; Rau et al., 1997) is not discernable in Kyllaren fjord; $\varepsilon_{\mathrm{p}}$ and $\mathrm{CO}_{2}$ values are for oxygenated surface waters ( $0-2 \mathrm{~m}$ depth).

likely that alternative carbon acquisition pathways are at work, such as active uptake of bicarbonate or non-Rubisco carboxylation enzymes such as PEP carboxylases, which are known to lead to considerably less fractionation in ${ }^{13} \mathrm{C}$ (Pancost et al., 1997; Korb et al., 1997).

At $4 \mathrm{~m}$ depth below the chemocline, an even smaller $\varepsilon_{\mathrm{p}}$ value is observed during the largest part of the year $(2-4 \%)$. This $\varepsilon_{\mathrm{p}}$ value is characteristic of green sulfur bacteria due to the utilization of the reductive tricarboxylic acid (TCA) cycle (Sirevåg, 1977; Quandt et al., 1977). At the time that $\varepsilon_{\mathrm{p}}$ values increased substantially from $3 \%$ (Julian day 238) to $21 \%$ (Julian day 283) at 4-m depth (Fig. 5d), a significant shift in the phytoplankton community occurred. During this period, the chemocline moved below $4 \mathrm{~m}$ depth (Fig. 3) and a peak in $\left[\mathrm{O}_{2}\right]$ of $\sim 15 \mathrm{mg} / \mathrm{l}$ occurred at $4 \mathrm{~m}$ depth. In addition, the [DIC] decreased by a factor two and became ${ }^{13} \mathrm{C}$-enriched by $\sim 13 \%$. These changes were likely related to the high density Euglena bloom observed at this depth. $\mathrm{Wu}$ and Scranton (1994) associated photosynthetic $\mathrm{O}_{2}$ production with a bloom of Euglena proxima found at the $\mathrm{O}_{2} / \mathrm{HS}^{-}$interface in a permanently anoxic estuarine basin (Pettaquamscutt River Estuary, Rhode Island). The decline in respired DIC contribution and the simultaneous ${ }^{13} \mathrm{C}$ depletion in POC $(-33.7 \%)$ at the chemocline in Kyllaren fjord can be attributed to photoautotrophic assimilation of respired DIC by $E u$ glena sp. Assuming that most of the POC is derived from Euglena sp., an $\varepsilon_{\mathrm{p}}$ value of $\sim 21 \%$ can be calculated, which is comparable to the $\varepsilon_{\mathrm{p}}$ value of 
$23.8 \pm 1.2 \%$ measured for Euglena gracilis (Sakashita et al., 2002). These comparable $\varepsilon_{\mathrm{p}}$ values suggest that Euglena sp assimilated respired DIC, resulting in the lowest observed $\delta^{13} \mathrm{C}_{\mathrm{POC}}$ in Kyllaren fjord (Fig. 5).

From the above it is clear that, due to changes in the plankton community, it is preferable not to use $\delta^{13} \mathrm{C}_{\mathrm{POC}}$ as an indication of the process of recycling of respired $\mathrm{CO}_{2}$. Biomarker lipids specific to groups of photosynthetic organisms may be more suitable for documenting this process (Wu and Scranton, 1994) and this approach will be employed in the future.

\subsection{Consequences of respired $\mathrm{CO}_{2}$ recycling for sedimentary organic carbon}

Even if the impact of recycling of respired $\mathrm{CO}_{2}$ was not evident from $\delta^{13} \mathrm{C}_{\mathrm{POC}}$ due to a generally low $\varepsilon_{\mathrm{p}}$, it may be possible to see its imprint on sedimentary organic carbon, as observed for Lake Mendota (Hollander and Smith, 2001). There is indeed a slight trend towards more negative $\delta^{13} \mathrm{C}_{\mathrm{TOC}}$ in the sediment from $18 \mathrm{~cm}$ depth to the surface sediment (Fig. 6), which might be attributed to a gradual intensification of anoxia in Kyllaren fjord with a concomitant increase in the fixation of respired $\mathrm{CO}_{2}$. Biomarkers for anoxic photosynthetic green sulfur bacteria were detected even at $50 \mathrm{~cm}$ down core, but their accumulation rate increased in the upper $10 \mathrm{~cm}$ (Smittenberg et al., 2004), indicating more extensive periods of photic zone euxinia, conditions favourable for the process of respired $\mathrm{CO}_{2}$ recycling.

The most negative $\delta^{13} \mathrm{C}(-26.7 \%)$ is found just below $5 \mathrm{~cm}$ depth and, in the upper $5 \mathrm{~cm}$, the $\delta^{13} \mathrm{C}$ value even slightly increases, in contradiction with the idea that recycling has intensified. However, potential sources for sedimentary organic carbon, e.g., terrestrial plant debris, algal biomass and microbial biomass, have changed over the history of the fjord and thus modified $\delta^{13} \mathrm{C}_{\mathrm{TOC}}$. Marine biomarker accumulation rates increased in the upper $10 \mathrm{~cm}$ while the accumulation rate of terrigenous biomarkers remained more or less constant (Smittenberg et al., 2004). Marine derived OM is generally depleted in ${ }^{13} \mathrm{C}$ relative to DIC by $25 \%$ (Rau et al., 1996) and terrigenous $\mathrm{OM}$ typically exhibits $\delta^{13} \mathrm{C}$ values of $-28 \%$ to $-32 \%$ (Tyson, 1995; Lockheart et al., 1997). Hence, an increase in the marine relative to the terrestrial contribution to the sedimentary $\mathrm{OC}$ may also have caused an increase in $\delta^{13} \mathrm{C}_{\mathrm{TOC}}$. On the other hand, compared to buried sediments, surface sediment could contain higher relative amounts of carbohydrate carbon, which is enriched by up to $9 \%$ ompared to total cell material (Van Dongen et al., 2002). Ongoing selective decomposition of OM by anaerobic bacteria could decrease $\delta^{13} \mathrm{C}_{\mathrm{TOC}}$ values below the sedimentwater interface.

\section{Conclusions}

DIC below the chemocline in Kyllaren fjord is almost entirely derived from OM and forms a potential ${ }^{13} \mathrm{C}$-depleted DIC source for photosynthesis. Partial mixing of the water column is evident from the $\delta^{13} \mathrm{C}_{\text {DIC }}$ decrease in the oxygenated surface waters, especially in autumn and winter. Although all prerequisites for the Küspert model are accounted for, the actual recycling of the respired $\mathrm{CO}_{2}$ is not evident from the $\delta^{13} \mathrm{C}$ values of POC. This is likely due to the large variability in the photosynthetic fractionation $\left(\varepsilon_{\mathrm{p}}\right)$ which is highly variable in Kyllaren fjord due to the wide variety of organisms contributing to POC. Only when POC is predominantly derived from a single organism, i.e., Euglena sp., is recycling of respired $\mathrm{CO}_{2}$ apparent in the $\delta^{13} \mathrm{C}$ value of POC. This suggests that compound specific $\delta^{13} \mathrm{C}$ measurements will be required to recognize the process of recycling of respired $\mathrm{CO}_{2}$.

\section{Acknowledgements}

Drs. R. Pancost and S. Bernasconi and an anonymous referee are thanked for their constructive comments which substantially improved the manuscript. This research was financed by a grant of the Netherlands Organization for Scientific Research (NWO) to JSSD. Fieldwork was made possible by a grant from the Schure-Beijerinck-Popping fund of the KNAW (Royal Netherlands Academy of Arts and Sciences) and by assistance of the students of the Department of Geology at the HSF University College, Norway. We thank Karel Bakker (NIOZ) for analytical assistance in determining [DIC] and $\left[\mathrm{H}_{2} \mathrm{~S}\right]$. Askvoll Community and The County Governor of Sogn og Fjordane County are acknowledged for information and support. The help of farmer Arne Frøholm during fieldwork is highly appreciated.

\section{Associate Editor-R.D. Pancost}

\section{References}

Arthur, M.A., Jenkyns, H.C., Brumsack, H.-J., Schlanger, S.O., 1990. Stratigraphy, geochemistry, and paleoceanography of organic carbon-rich cretaceous sequences. In: Ginsburg, R.N., Beaudoin, B. (Eds.), Cretaceous Resources, Events and Rhythms. Kluwer Academic Publishers, Netherlands, pp. 75-119.

Bernasconi, S., Hanselmann, K., 1995. The influence of bacterial activity at the chemocline on particulate organic matter fluxes and nutrient cycling in meromictic Lake Cadagno. Organic geochemistry: developments and applications to energy, climate, environment and human history. A.I.G.O.A., San Sebastián, pp. 1169-1171. 
Deevey, E.S., Nakai, N., Stuiver, M., 1963. Fractionation of sulfur and carbon isotopes in a meromictic lake. Science 139, 407-408.

Deevey, E.S., Stuiver, M., 1964. Distribution of natural isotopes of carbon in Linsley Pond and other New England lakes. Limnology and Oceanography 9, 1-11.

Descolas-Gros, C., Fontagne, M., 1990. Stable carbon isotope fractionation by marine phytoplankton during photosynthesis. Plant, Cell and Environment 13, 207-218.

Dickens, G.R., O’Neil, J.R., Rea, D.K., Owen, R.M., 1995. Dissociation of oceanic methane hydrate as a cause of the carbon isotope excursion at the end of the Paleocene. Paleoceanography 10, 965-971.

Dickson, A.G., Goyet, C. (Eds.), 1994. Water sampling for the parameters of the oceanic carbon dioxide system. In: Handbook of Methods for the Analysis of the Various Parameters of the Carbon dioxide System in Sea Water. ORNL/CDIAC-74, pp. 1-6.

DNMI, 2004. Monthly climatological observation. Det Metereologisk Institutt (Norwegian Metereological Institute), Blinder, University of Oslo, Ref type: Electronic citation.

Farquhar, G.D., Oleary, M.H., Berry, J.A., 1982. On the relationship between carbon isotope discrimination and the intercellular carbon dioxide concentration in leaves. Australian Journal of Plant Physiology 9, 121-137.

Francois, R., Altabet, M.A., Goericke, R., 1993. Changes in the $\delta^{13} \mathrm{C}$ of surface water particulate organic matter across the subtropical convergence in the SW Indian Ocean. Global Biogeochemical Cycles 7, 627-644.

Freeman, K.H., Wakeham, S.G., Hayes, J.M., 1994. Predictive isotopic biogeochemistry: hydrocarbons from anoxic marine basins. Organic Geochemistry 21, 629-644.

Fry, B., 1986. Sources of carbon and sulfur nutrition for consumers in three meromictic lakes of New York State. Limnology and Oceanography 31, 79-88.

Fry, B., Jannasch, H.W., Molyneaux, S.J., Wirsen, C.O., Muramoto, J.A., King, S., 1991. Stable isotope studies of carbon, nitrogen and sulfur cycles in the Black Sea and the Cariaco Trench. Deep-Sea Research 38, S1003-S1019.

Hesselbo, S.P., Gröcke, D.R., Jenkyns, H.C., Bjerrum, C.J., Farrimond, P., Morgans Bell, H.S., Green, O.R., 2000. Massive dissociation of gas hydrate during a Jurassic oceanic anoxic event. Nature 406, 392-395.

Hollander, D.J., Smith, M.A., 2001. Microbially mediated carbon cycling as a control on the $\delta^{13} \mathrm{C}$ of sedimentary carbon in eutrophic Lake Mendota (USA): new models for interpreting isotopic excursions in the sedimentary record. Geochimica et Cosmochimica Acta 65, 4321-4337.

Klein Breteler, W.C.M., Grice, K., Schouten, S., Kloosterhuis, H.T., Sinninghe Damsté, J.S., 2002. Stable carbon isotope fractionation in the marine copepod Temora longicornis: unexpectedly low $\delta^{13} \mathrm{C}$ value of faecal pellets. Marine Ecology-Progress Series 240, 195-204.

Korb, R.E., Saville, P.J., Johnston, A.M., Raven, J.A., 1997. Sources of inorganic carbon for photosynthesis by three species of marine diatom. Journal of Phycology 33, 433440.

Kroopnick, P., 1985. The distribution of ${ }^{13} \mathrm{C}$ of $\sum \mathrm{CO}_{2}$ in the world oceans. Deep-Sea Research 32, 57-84.

Küspert, W., 1982. Environmental changes during oil shale deposition as deduced from stable isotope ratios. In:
Einsele, G., Seilacher, A. (Eds.), Cyclic and Event Stratification. Springer, Heidelberg, pp. 482-501.

Lockheart, M.J., Bergen, P.F., Evershed, R.P., 1997. Variations in the stable carbon isotope compositions of individual lipids from leaves of modern angiosperms: implications for the study of higher land plant-derived sedimentary organic matter. Organic Geochemistry 26, 137-153.

Menegatti, A.P., Weissert, H., Brown, R.S., Tyson, R.V., Farrimond, P., Strasser, A., Caron, M., 1998. High-resolution $\delta^{13} \mathrm{C}$ stratigraphy through the early Aptian "Livello Selli" of the Alpine Tethys. Paleoceanography 13, 530-545.

Mook, W.G., Bommerson, J.C., Staverman, W.H., 1974. Carbon isotope fractionation between dissolved bicarbonate and gaseous carbon dioxide. Earth and Planetary Science Letters 22, 169-176.

Murray, J.W., Top, Z., Özsoy, E., 1991. Hydrographic properties and ventilation of the Black Sea. Deep-Sea Research 38, S663-S689.

Paetzel, M., Schrader, H., 1995. Sewage history in the anoxic sedimetns of the fjord Nordåsvannet, western Norway. Norsk Geologisk Tidsskrift 75, 146-155.

Pancost, R.D., Freeman, K.H., Wakeham, S.G., Robertson, C.Y., 1997. Controls on carbon isotope fractionation by diatoms in the Peru upwelling region. Geochimica et Cosmochimica Acta 61, 4983-4991.

Pletsch, T., Erbacher, J., Holbourn, A.E.L., Kuhnt, W., Moullade, M., Oboh-Ikuenobe, F.E., Söding, E., Wagner, T., 2000. Cretaceous separation of Africa and South America: the view from the West African margin (ODP Leg 159). Journal of South American Earth Sciences 14, 147-174.

Popp, B.N., Laws, E.A., Bidigare, R.R., Dore, J.E., Hanson, K.L., Wakeham, S.G., 1998. Effect of phytoplankton cell geometry on carbon isotopic fractionation. Geochimica et Cosmochimica Acta 62, 69-77.

Poulsen, C.J., Barron, E.J., Arthur, M.A., Peterson, W.H., 2001. Response of the mid-cretaceous global oceanic circulation to tectonic and $\mathrm{CO}_{2}$ forcings. Paleoceanography 16 , 576-592.

Quandt, L., Gottschalk, G., Ziegler, H., Stichler, W., 1977. Isotope discrimination by photosynthetic bacteria. Fems Microbiology Letters 1, 125-128.

Quay, P.D., Emerson, S.R., Quay, B.M., Devol, A.H., 1986. The carbon cycle for Lake Washington - a stable isotope study. Limnology and Oceanography 31, 596-611.

Rau, G.H., 1978. Carbon-13 depletion in a subalpine lake: carbon flow implications. Science 201, 901-902.

Rau, G.H., Riebesell, U., Wolf-Gladrow, D.A., 1996. A model of photosynthetic ${ }^{13} \mathrm{C}$ fractionation by marine phytoplankton based on diffusive molecular $\mathrm{CO}_{2}$ uptake. Marine Ecology Progress Series 133, 275-285.

Rau, G.H., Riebesell, U., Wolf-Gladrow, D.A., 1997. $\mathrm{CO}_{2 \mathrm{aq}^{-}}$ dependent photosynthetic ${ }^{13} \mathrm{C}$ fractionation in the ocean: a model versus measurements. Global Biogeochemical Cycles 11, 267-278.

Rau, G.H., Takahashi, T., Desmarais, D.J., Repeta, D.J., Martin, J.H., 1992. The relationship between $\delta^{13} \mathrm{C}$ of organic matter and $\left[\mathrm{CO}_{2}(\mathrm{aq})\right]$ in ocean surface water: data from a JGOFS site in the northeast Atlantic Ocean and a model. Geochimica et Cosmochimica Acta 56, 1413-1419. 
Richards, F.A., 1965. Anoxic basins and fjords. In: Riley, J.P., Skirrow, G. (Eds.), Chemical Oceanography, vol. I. Academic Press, London, pp. 611-643.

Riebesell, U., Burkhardt, S., Dauelsberg, A., Kroon, B., 2000. Carbon isotope fractionation by a marine diatom: dependence on the growth-rate-limiting resource. Marine Ecology Progress Series 193, 295-303.

Sakashita, T., Doi, M., Nakamura, Y., Fuma, S., Ishii, N., Takeda, H., 2002. $\gamma$-Irradiation effect: variation of photosynthetic activity of Euglena. Biomedical and Environmental Sciences 15, 261-267.

Schlanger, S.O., Jenkyns, H.C., 1976. Cretaceous oceanoc anoxic events: causes and consequences. Geologie en Mijnbouw 55, 179-184.

Schouten, S., van Kaam-Peters, H.M.E., Rijpstra, W.I.C., Schoell, M., Sinninghe Damsté, J.S., 2000. Effects of an oceanic anoxic event on the stable carbon isotopic composition of early toarcian carbon. American Journal of Science $300,1-22$

Sharkey, T.D., Berry, J.A., 1985. Carbon isotope fractionation of algae as influenced by an inducible $\mathrm{CO}_{2}$ concentrating mechanism. In: Lucas, W.J., Berry, J.A. (Eds.), Inorganic Carbon Uptake by Aquatic Photosynthetic Organisms. The American society of plant physiologists, Rockville, MD, pp. 389-401.

Sirevåg, R., Buchanan, B.B., Berry, J.A., Troughton, J.H., 1977. Mechanisms of $\mathrm{CO}_{2}$ fixation in bacterial photosynthesis studied by the carbon isotope fractionation technique. Archives of Microbiology 112, 35-38.

Smittenberg, R.H., Pancost, R.D., Hopmans, E.C., Paetzel, M., Sinninghe Damsté, J.S., 2004. A 400-year record of environmental change in an euxinic fjord as revealed by the sedimentary biomarker record. Palaeogeography, Palaeoclimatology, Palaeoecology 202, 331-351.

Stoll, M.H.C., 1994. Inorganic carbon behaviour in the North Atlantic Ocean, PhD thesis, university of Groningen, The Netherlands, p. 193.

Stoll, M.H.C., Bakker, K., Nobbe, G.H., Haese, R.R., 2001. Continuous-flow analysis of dissolved inorganic carbon content in seawater. Analytical Chemistry 73, 4111-4116.

Syvitski, J.P.M., Burrell, D.C., Skei, J.M., 1987. Fjords Processes and Products. Springer Verlag, New York.

Tyson, R.V., 1995. Bulk geochemical characterizations and classification of organic matter: stable carbon isotopes $\left(\delta^{13} \mathrm{C}\right)$. In: Sedimentary Organic Matter. Chapman \& Hall, London, pp. 395-416.

Van Dongen, B.E., Schouten, S., Sinninghe Damsté, J.S., 2002. Carbon isotope variability in monosaccharides and lipids of aquatic algae and terrestrial plants. Marine Ecology-Progress Series 232, 83-92.

Velinsky, D.J., Fogel, M.L., 1999. Cycling of dissolved and particulate nitrogen and carbon in the Framvaren Fjord, Norway: stable isotopic variations. Marine Chemistry 67, 161-180.

Volkov, I.I., 2000. Dissolved inorganic carbon and its isotopic composition in the waters of anoxic marine basins. Oceanology 40, 499-502.

Wachniew, P., Rózanski, K., 1997. Carbon budget of a midlatitude, groundwater-controlled lake: isotopic evidence for the importance of dissolved inorganic carbon recycling. Geochimica et Cosmochimica Acta 61, 2453-2465.

Wu, H., Scranton, M.I., 1994. Cycling of some low molecular weight volatile fatty acids in a permanently anoxic estuarine basin. Marine Chemistry 47, 97-113. 